\title{
A Monetary/Exchange-rate Strategy For the Reconstruction of IraQ
}

\author{
Robert Looney
}

Dr. Looney is a professor in the Department of National Security Affairs, Naval Postgraduate School, Monterey, CA.

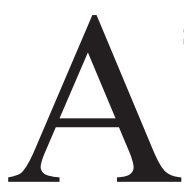

$\mathrm{s}$ the military conflict for Iraq concluded, a new battle began over the best way to rebuild the Iraqi economy. On the one side are those who believe that, by establishing proper institutions and rules, the Iraqis will be able to rebuild their own economy without an extended period of outside oversight and massive financial assistance. Another side sees the necessity of substantial infusions of foreign assistance and technical support over an extended period of time. A possible third group, primarily led by the French and Russians, feels that a new Iraqi government should set a high priority on paying back the tens of billions of dollars in loans taken out by Saddam's government. ${ }^{1}$ While differing somewhat on ends and means, no doubt all sides would agree that any recovery of the Iraqi economy will entail successfully addressing a daunting set of tasks:

- Repairing a wrecked and neglected banking system that currently has at least three currencies in circulation: "Swiss" dinars, "Sadaam" dinars, and now U.S. dollars.

- Beginning the servicing and restructuring of the country's massive national debt.
- Resurrecting a whole spectrum of dilapidated industries.

- Revitalizing a declining and neglected agricultural sector.

- Propelling an economy based largely on cash, barter and international assistance into the twenty-first century.

- Reestablishing a consuming middle class that has all but disappeared.

- Diversifying an economy that currently depends upon a single commodity: oil.

- Replacing graft and corruption with a streamlined government that can collect taxes and enforce contracts.

- Commencing privatizing of inefficient public enterprises.

Although forging the country's economic recovery will be a daunting task, a number of lessons are apparent from the experiences of former Soviet-bloc countries, as well as the reform programs of many of the formerly inward-oriented Latin American economies. Over the last several decades, more than a dozen countries, ranging from Chile to Poland, have gone through a transition from stagnant socialist to vibrant free-market democratic economies. Although each of these countries is unique in many regards, there are enough 
similarities to provide a rough understanding of what works and what doesn't.

Uppermost is the establishment of the rule of law, an honest court system, and the protection of private property. Those formerly socialist countries that continued to have corrupt and uncertain judicial systems have had poor economic performance despite considerable economic reform. If private property rights are not protected, few will invest. ${ }^{2}$

Another lesson learned from the transition-economy experience is that progress will be difficult without the creation of a sound monetary system. Iraq has suffered very high rates of inflation in recent years, but, given the oil wealth of the country, a sound currency could be quickly created. One obvious solution is to simply dollarize (or even euroize) the economy. ${ }^{3}$ This could be done even before the creation of a new central bank. Specifically, simply let the dollar (or euro) circulate as the principal means of payment, with the money supply, as in the old gold standard, ultimately determined by the country's balance-of-payments position. Several countries including Panama, Ecuador and El Salvador currently use the dollar as their official currency.

Another alternative would be the creation of a new Iraqi dinar. Here a set of follow-on issues entail (a) what rules should be used by an Iraqi Central Bank in issuing new dinars? and (b) how should the exchange rate be set with regard to other currencies? The sections below focus on these issues in an attempt to identify the best monetary system for facilitating Iraq's reconstruction, restructuring and future economic growth.

\section{IMMEDIATE POST-CONFLICT SITUATION}

The country's 24 million people are currently struggling to subsist in an economy based largely on cash, barter and international handouts. As Veith notes,

\begin{abstract}
The nation is hobbled by high unemployment, poverty, spiraling inflation, and rampant corruption. Its middle class has all but disappeared. Taxes go uncollected, contracts unpaid. Agriculture has withered and other industries have collapsed. There are no official budgets or economic statistics. The government depends almost wholly on exports of a single commodity, petroleum, subject to sharp price swings. ${ }^{4}$
\end{abstract}

Of particular concern is the country's external debt. While a precise figure is unavailable, the country's external financial obligations consist roughly of $\$ 127$ billion in debt, $\$ 57$ billion in pending contracts (mostly with Russian companies), and \$27 billion in compensation due to victims of the Iraqi invasion of Kuwait. Debts to Kuwait are estimated at around $\$ 17$ billion, to other Gulf states $\$ 30$ billion, and to Russia around $\$ 12$ billion. $^{5}$

Another problem area is the country's entire financial system. Baghdad's financial district is a mass of blown-out vaults, burned-out buildings and broken glass. All nine floors of the Iraqi Central Bank have collapsed into a hollow shell.

Decades ago, Iraq's financial system was one of the region's most modern; its pool of well-educated technocrats helped other Middle Eastern countries, such as Jordan, establish their central banks. Unfortunately, the system was run into the ground by Saddam Hussein, who treated 
the Central Bank as his own private account. Under Hussein, the bank lost its independent power to regulate exchange rates and interest rates.

Before the war, there were a few private banks, but the system was dominated by four state-run lenders. Baath party loyalists received preferential loans from these banks. However, few Iraqis had bank deposits because of fear of seizure. ${ }^{6}$ In short, a whole new financial system will have to be created as part of the early reconstruction effort.

\section{INITIAL STEPS TOWARD RECONSTRUCTION}

At the end of the war, work on these problems began across a wide set of fronts:

1. One of the key missions of the U.S. Treasury Department's advance team in Iraq has been to gather basic information ${ }^{7}$ about economic conditions in the country so that officials in Washington can make intelligent decisions on the best path to take towards alleviating bottlenecks and encouraging private participation. This fact-finding draws on Treasury expertise gained in assessing the prospects of many of the former Soviet economies at the time of their independence.

2. Immediate tasks include paying government salaries, determining the dinar's value, and establishing U.S. oversight of Iraq's central bank, Finance Ministry and other key agencies.

3. Concurrently, officials in Washington and perhaps the United Nations are expected to take initial steps to restore oil production, launch public-works projects, mobilize donors, seek debt relief, stabilize the currency, cover balance-of-payments shortfalls, provide investment safeguards and help draft a government budget.

4. Although vague at this time, ${ }^{8}$ the international community is also expected to encourage the new government of Iraq to pursue ambitious longer-term reforms, such as modernizing commercial banking, reforming the tax system, lowering tariffs and other trade restrictions, soliciting foreign investment, pursuing industrial diversification and privatizing governmentrun industries.

\section{Currency Instability}

An immediate concern has been the country's chaotic currency situation. After the Gulf War, Iraq replaced the old "Swiss" dinars (as they were known because they were printed in Switzerland) with "Saddam" dinars, and then printed everlarger quantities to make up for the government's chronic budget shortfalls. Though the government maintained the official exchange rate of Saddam dinars at 0.3 to the dollar, the black market exchange rate reached 2,000 to the dollar by the time Coalition Forces attacked Iraq. By the end of April 2003, their value was around 3,000 to the dollar.

Although not printed since 1990, the older, "Swiss" dinars continue to circulate in the autonomous Kurdish regions of northern Iraq. Most are ragged, sometimes held together with tape, and there is no central bank that controls their supply they simply recirculate in the regions. ${ }^{9}$ Through March 2003 and into early April of this year, speculative buying had doubled the dollar value of these "Swiss" dinars.

U.S. Treasury officials are in the process of assessing the possibilities for printing new batches of the Swiss dinars in either Iraq or abroad. Although Iraq did have printing and engraving plants, officials 
say they do not yet know how many of them are still functional or whether they can produce bills with modern anticounterfeiting features like holograms. ${ }^{10}$

Until a new system is established, the dollar will also be an "official" currency. The dollar has circulated widely in Iraq for years. By some estimates, Treasury officials say, as much as $\$ 500$ million may have been circulating before the war. Small-denomination dollars notes will be put into circulation through "emergency" payments to hundreds of thousands of Iraqi civil servants in an effort to quiet civic unrest and to stabilize the economy. ${ }^{11}$

American officials are working with finance and postal-ministry officials from Saddam Hussein's government to figure out appropriate wages. Under the Hussein regime, the central government tightly controlled wages and prices. Setting wages too high could worsen inflation, which is already running at about 70 percent annually. At first, the Iraqi workers will be given $\$ 20$ each in $\$ 1$ and $\$ 5$ bills. That is a large sum in Iraq, where a mid-level oil professional with a chemistry degree used to make the equivalent of $\$ 50$ a month.

Also, with no central bank or functional commercial banking system, the U.S.

Agency for International Development will begin offering loans of between $\$ 100$ and $\$ 250,000$ to individual entrepreneurs and to small to medium-sized businesses. With no central bank or economic mechanisms to control the volume of dollars in circulation, however, there is no assurance that inflation can be curbed or resources allocated efficiently. Clearly, a top priority in reconstruction will have to be the establishment of a central bank that can oversee the country's monetary and financial system.

\section{POSSIBLE EXCHANGE RATES}

With the establishment of a central bank, the first issue at hand is whether it should immediately begin to issue its own currency. If it does, what are the policy options available? Which are superior? While a whole spectrum of flexible exchange-rate systems are possible - managed flexible rates, gliding bands, adjustable pegs, etc. - given the dearth of financial and administrative expertise to properly manage a flexible-rate system, this option can be immediately ruled out as providing the stability needed over the next decade or so for reconstruction, though they are certainly realistic alternatives after the country has developed a sound financial system and is integrated into the global economy. Given this reality, the discussion below will be confined to the relative advantages and disadvantages of possible fixed-rate systems.

\section{Currency Union}

If Iraq opted for this option, a foreign currency would act as legal tender. Monetary policy would simply be delegated to the anchor (country of currency origin); the currency that circulates domestically would be literally the same as that circulating in one of the major economies, probably the dollar or possibly the euro.

The motivation underlying this choice would be to get the maximum credibility for inflation-resistant monetary policy. Clearly, maximum credibility derives from the fact that the country simply did not have a monetary policy because it lacked a currency to print. In technical terms, it would largely eliminate the occurrence of a phenomenon that economists have dubbed the "time-inconsistency problem" - the fact that a government's incentive today to 
keep inflation low does not mean that a government will have the same incentive tomorrow. For example, one of the new political parties in Iraq may be elected on the promise that it will reduce inflation. After a few years in office, but before the next election, the party may begin to reconsider its original position. It will realize that it can probably gain additional political support if it increases the money supply to pay for extra social programs without directly taxing citizens. Moreover, inflation will not become apparent until after the elections.

The problem for the government is that over time people are not stupid. After the first bout of inflation, individuals will anticipate from the start the government's incentive to inflate before its term is overthe voters may never lower their inflation expectations. The problem is compounded when the government in power today may not be the government in power tomorrow. Consequently, any anti-inflation statements that a political party makes will not be believed. This is the essence of the timeinconsistency problem and why governments, in order to create a credible antiinflation policy, may want to have an independent central bank that does not have the same incentives to inflate as do elected members of government. An independent central bank (or in this case the lack of a central bank) can make it more difficult if not impossible for current and future governments to change course on monetary policy.

Use of another country's currency would not be without its own set of problems. These fall into three main categories. First, the optimal-currency-area literature suggests that real shocks (for example, terms-of-trade shocks) are better accommo- dated through flexible exchange rates, and nominal shocks (for example moneydemand shocks) through fixed exchange rates. Iraq would no doubt experience greater external than internal shocks during most of the reconstruction process. Because the country has virtually no money markets, fluctuations in oil revenues would be buffeted by movements in the country's real exchange rate, if it had its own currency. Using the dollar, however, would force these adjustments on the domestic economy - less output, more unemployment.

Domestic economic contractions of this sort would be especially the case if Iraq's economy was not in the same phase of the business cycle as that of the country of currency origin. For example, a dramatic fall in oil prices would stimulate output and production in the United States, perhaps to the point where monetary policy tightened to choke off excess demand. The subsequent increase in Iraqi interest rates would only accentuate the drop in aggregate demand in that country, thus compounding the severity of the oil-price drop.

Warner sums up this aspect of possible dollarization in Iraq:

The supply of dollars would be determined by the U.S., the interest rates would be determined by the U.S., and in effect Iraq's capacity to borrow would be determined by the U.S. It scarcely needs saying that what might be important to Iraq would not merit so much as a mention at the monthly meetings of the Federal Reserve's Open Market Committee to determine monetary policy. The Cincinnati Catfish Company would get a better look than Iraq. ${ }^{12}$

Second, there would be no seignorage 
revenues - the difference between the cost of printing money and the non-inflationary value of goods and services the authorities could purchase with the newly issued money. This can be a fairly sizable amount. Studies have shown that this is likely to be at least twice the country's pre-dollarization monetary base, ${ }^{13}$ or in Iraq's case, millions and millions of dollars over time. However, under the circumstances, the authorities might be able to negotiate a seignoragesharing agreement whereby the United States compensated Iraq for its lost income.

Third, Iraq would lack the lender-oflast resort function - the ability of the central bank to discount commercial-bank paper would be lost. In difficult times, commercial banks would not be able to build up their reserves by selling their assets at stable values to the central bank. Depending on its holdings of dollars/euros, the fiscal authority (Ministry of Finance, for example) might be able to perform the lender-of-last-resort function, but this would not be assured. In short, dollarization does not necessarily imply the loss of a lender of last resort, but simply the disappearance of one particular source of liquidity, namely central-bank credit.

In sum, dollarization (or euroization) would have the chief advantage of providing a stable monetary environment for the country to recover. The system would place few demands on the country's monetary authorities, allowing the central bank breathing space to upgrade its staff to the point (in a decade or so) where more sophisticated monetary management would be feasible. There would be costs, perhaps the highest being the political/psychological one of appearing to be a colony of the United States. This alone might rule out dollarization.

\section{Currency Board}

Under this system, Iraq would have its own "currency." But it would be constrained in managing that currency: (a) the dollar/"dinar" exchange rate would be fixed not just by policy, but by law; (b) a reserve requirement stipulating that each dollar/euro's worth of domestic currency is backed by a dollar/euro's worth of foreign reserves; and (c) a self-correcting balanceof-payments mechanism, in which a payments deficit automatically contracts the money supply, resulting in a contraction of spending. Like dollarization, a currency board can help to create a credible policy environment by removing from the monetary authorities the option of printing money to finance government deficits.

The first currency board was established by the British in Mauritius in 1849 . The use of currency boards eventually spread to 70 British colonies. The purpose was to provide the colonies with a stable currency without the associated difficulty of issuing sterling notes and coins that were costly to replace if lost or destroyed. The colonies also benefited from this approach, in that they could earn interest on the foreign-currency assets being held in reserve. The use of currency boards peaked in the 1940s and declined thereafter. In the 1960s, many newly independent African countries replaced their currency board with a central bank, and most other countries followed suit in the 1970s.

There is certainly precedent for this type of system in Iraq, and in fact historically Iraq has used a system similar to that adopted by many of the former British colonies. When Iraq was part of the Ottoman Empire, a number of European currencies circulated alongside the Turkish pound. With the establishment of the 
British mandate after World War I, Iraq was incorporated into the Indian monetary system, which was operated by the British, and the rupee became the principal currency in circulation.

In 1931, the Iraq Currency Board was established in London for note issue and maintenance of reserves for the new Iraqi dinar. The currency board pursued a conservative monetary policy, maintaining very high reserves behind the dinar. The dinar was further strengthened by its link to the British pound. In 1947 the governmentowned National Bank of Iraq was founded, and in 1949 the London-based currency board was abolished as the new bank assumed responsibility for the issuing of notes and the maintenance of reserves. The National Bank of Iraq continued the currency board's conservative monetary policy, maintaining 100-percent reserves behind outstanding domestic currency.

In more recent times, another Gulf country, the UAE, had considerable success with a currency board. This board was established in 1973 mainly for issuing the national currency, the dirham, and defending its parity (which was set at 0.186621 grams of gold; in terms of U.S. dollars it was 3.94737 dirhams for one U.S. dollar, with a margin of fluctuation of plus or minus one percent).

Prior to the creation of the Currency Board, and from the time the Trucial States abandoned the Indian Gulf rupee in 1966, various regional currencies such as the Bahraini dinar and the Saudi and Qatari/ Dubai riyals had served as local currencies in one emirate or another. The board was given the authority not only to issue a common currency for the union, but also to exercise central-banking functions over the commercial and banking sector. ${ }^{14}$ As with the case of Iraq noted above, the Currency Board was eventually phased out for a more traditional central bank with the power to issue its own money, not necessarily backed up by foreign assets.

The introduction of currency-board-like arrangements in Hong Kong (1983), Argentina (1991), Estonia (1992), Lithuania (1994), Bulgaria (1997), Bosnia (1998), Ecuador (2000) and El Salvador (2001) constitutes their resurgence in recent years. Clearly, however, the Argentine experience has forced a closer examination of the usefulness of this system. However, Hanke has noted that the main problem in Argentina was that the system was a "currency-board-like" system and not a true currency board. ${ }^{15}$

Currency boards are not a panacea, and while one could produce the stability required for Iraqi reconstruction, it would unlikely succeed indefinitely without reforms to increase competitiveness. This was Argentina's downfall. After an impressive start, the Argentine government failed to liberalize trade enough to sufficiently expand exports. They failed to change restrictive labor laws. They raised taxes above U.S. levels. The result was that Argentina was not enough of a contender to withstand external shocks or count on future investor confidence. ${ }^{16}$

The main advantage of the Currency Board over the Currency Union is largely that of political/national pride. However, on the assumption that over time the country's economic institutions develop and mature, the currency board might be a good transition to a more flexible exchange-rate system more under control of the Iraqi authorities. Also on the plus side, the timeinconsistency problem noted above would be reduced, but now subject to the per- 
ceived probability that the Board might be abandoned. As with the Currency Union, real-exchange-rate volatility would be diminished.

\section{Monetary Union}

A monetary union for Iraq would entail accepting a common currency issued by a common regional central bank. At present, there are no regional unions of this sort Iraq might join, although the GCC countries are in the process of forming a currency union, the completion date of which is tentatively set for 2010 - too far in the future to be of assistance for the country's reconstruction. In any case, Iraq's membership in the GCC monetary union is quite problematic at this point. Iraq's population is considerably larger than that of any of the GCC countries, implying that Iraq might have considerable advantages in industrialization, thus being a threat to several existing GCC members, notably Saudi Arabia.

The benefits of a monetary union are similar to the first two systems examined above. It would also reduce the timeinconsistency problem by requiring multinational agreement on policy. Real-exchangerate volatility would also probably be reduced. For both, however, the result would be less certain than in the case of dollarization or a classic currency board. It would have all of the disadvantages associated with both systems.

\section{Traditional Peg}

This system would entail setting a fixed rate between the new Iraqi currency and either the dollar or the euro (or some index weighted by the two). The potential benefit is that the time-inconsistency problem would be reduced through commitment to a verifiable target. The system is more flexible than the currency board, in that a devaluation option would always be open, thus providing a potentially valuable policy tool in response to large shocks. The system would also reduce real-exchangerate volatility. However, the ability to periodically change the exchange rate is also the system's most serious limitation, with the possibility of instability stemming from investor speculation over possible rate changes.

In addition, because the system would relax the fiscal constraint on government expenditures (the dinar would no longer have a one-to-one backing of dollar/euro reserves), inflationary pressures might develop. In turn, these could lead to the socalled Dutch Disease effect, ${ }^{17}$ characterized by an overvalued foreign-exchange rate limiting the ability of the country to develop broad-based diversification into export markets. Through cheapening imports, the exchange rate would also limit import-substitution industrialization for the large domestic market.

Finally, because of the increased uncertainty surrounding possible devaluations, the exchange rate would, from time to time become a target for speculative attacks, especially during periods of low reserves and/or high external-debt-servicing commitments. In short, the pegged rate would avoid real-exchange-rate volatility, but not necessarily persistent misalignments. The approach does not by itself place hard constraints on monetary and fiscal policy and thus provides only a partial solution against the time-inconsistency problem. The credibility effects depend on accompanying institutional measures and the record of accomplishment. Here the authorities could gain considerable cre- 
dence by introducing and successfully managing an oil-revenue-stabilization fund. Proper management of the fund would smooth out oil expenditures leading to reduced inflationary pressures and exchange-rate issues: doubts about sustainability in the presence of full capital mobility.

\section{CONCLUSIONS}

The main considerations concerning possible monetary and exchange-rate systems in Iraq are summarized in Figure 1. Considering the current disarray of the Iraqi economy, dollarization is likely to be the best system to initiate in the country. This system would provide stability while making limited demands on the country's central bank and money managers.

No doubt, the political sensitivities of a new Iraqi government will soon dictate the initiation of a new Iraqi currency. In fact, on July 7, U.S. officials announced that, beginning on October 15,2003, they would replace the circulating Iraqi currency with a new one. ${ }^{18}$ At that time, the central bank will also be restructured to give it more autonomy. While the U.S. announcement was not specific as to how the central bank will conduct monetary/exchange-rate policy, the discussion above suggests that the currency-board option appears to be the best alternative. The system would provide the country with price stability. It would also be consistent with the economy's gradual liberalization and integration into the world economy. Most important, such a system would also restore foreign confidence in the country's ability to provide a stable environment for investment. However, a currency board would probably not be optimal in the longer term.

\section{Figure 1: Alternative Monetary Systems and Implementation Strategies for Iraq}

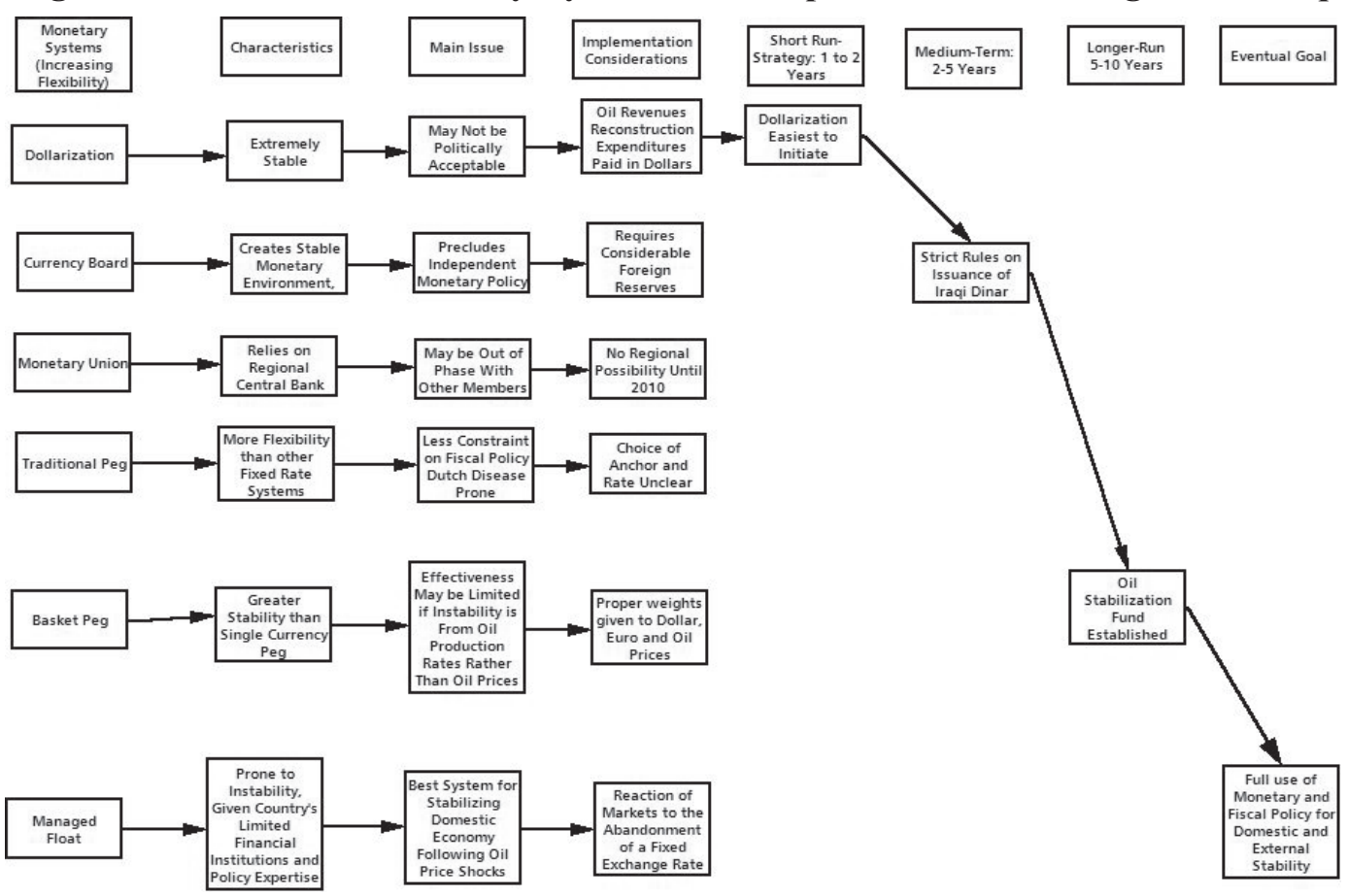


A country of Iraq's economic size will eventually grow to the point where a more flexible system would provide a better tool for macroeconomic management of the domestic economy. Still, the board would provide the Iraqi authorities with some breathing space until a new central bank had gathered the experience and expertise to introduce a more complex, flexible exchange-rate system. At that point the country could move to a fixed exchange rate, linking the Iraqi dinar to the dollar/ euro or some basket of the two.
To avoid an overvaluation of the dinar and possible Dutch Disease effects, ${ }^{19}$ the country should simultaneously have a fiscal policy built around an oil stabilization fund. ${ }^{20}$ In turn, the fund would be designed to smooth out, as much as feasible, fluctuations in oil revenues. Over time, successful management of the fund could contribute to the stability of the exchange rate and thus the country's completion of the reconstruction and restructuring of its economy.

${ }^{1}$ Richard Rahn, “Coming Battle to Restore Iraq's Economy,” The Washington Times, April 9, 2003.

2 "Rebuilding Iraq," The Economist, April 17, 2003.

${ }^{3}$ Steve Hanke "The Euro Could Help Iraq's Economic Revovery," Financial Times, April 16, 2003.

${ }^{4}$ Warren Veith, "Teams Prepare to Jump-Start Iraq's Economy: The U.S. is Helping Lay the Groundwork for a Wide Range of Monetary, Fiscal, and Private Sector Reforms in the War-Ravaged Country," The Los Angeles Times, April 12, 2003.

${ }^{5}$ Irwin M. Stelzer, "Forgive Them His Debts: How Much of Saddam's Financial Baggage Should the Iraqi People Have to Carry?" The Weekly Standard, April 12, 2003.

${ }^{6}$ Hans Greimel, "Iraq's Dire Banking Blues: With the Country's Entire Financial System in Tatters, a New Central Bank is Seen as a Top Priority," Ottawa Citizen, April 22, 2003.

${ }^{7}$ Bob Davis and Hugh Pope, "Numbers Crunch: Once an Economic Dynamo, Iraq is Now Financial Riddle To Rebuild Nation, U.S. First Must Find Reliable Data," The Wall Street Journal, April 9, 2003.

${ }^{8}$ Gary Duncan, "IMF Haze Obscures Iraq's Horizon," London Times, April 14, 2003.

${ }^{9}$ Edmund L. Andrews, "Iraq to Run of Dollars Till It Gets New Currency," New York Times, April 18, 2003.

${ }^{10}$ Ibid.

11 "Iraq's Currency Hodgepodge: Officials to Begin Payments Using U.S. Dollars, but Everything Else in Circulation Will Be Accepted," Associated Press, April 16, 2003.

${ }^{12}$ Jeremy Warner, "Iraq's Dollarization," The Independent, April 18, 2003.

${ }^{13}$ Stephanie Schmitt-Grohe and Martin Uribe, "Stabilization Policy and the Costs of Dollarization," Departmental Working Papers Series, Rutgers University Department of Economics.

${ }^{14}$ Ali Mohammed Khalifa, The United Arab Emirates: Unity in Fragmentation, (Boulder, CO: Westview Press, 1970), p. 63.

${ }^{15}$ Hanke, "The Euro Could Help Iraq's Economic Revovery."

${ }^{16}$ Amity Shlaes, "It is Dangerous to Elevate a Currency as a Political Emblem if the Need for Other Economic Reforms Is Obscured," Jewish World Review, 2002.

${ }^{17}$ Robert E. Looney, Oil Revenues and Viable Development: Impact of Dutch Disease on Saudi Arabian Diversification Efforts," American-Arab Affairs, Winter 1988-1989.

${ }^{18}$ Richard A. Oppel, "Iraq To Get New Currency and Autonomous Central Bank," July 7, 2003.

${ }^{19}$ Christine Ebrahimzadej, "Dutch Disease: Too Much Wealth Managed Unwisely," Finance and Development, March 2003.

${ }^{20}$ Steven Barnett and Rolando Ossowski, "What Goes Up ... Why Oil Producing States Must Husband Their Resources," Finance and Development, March 2003. 